\title{
Czy sieć zastąpi szkołę i rodziców w edukacji i wychowaniu?
}

\begin{abstract}
Bogusław Śliwerski, Czy sieć zastąi szkołę i rodziców w edukacji i wychowaniu? [Will the Internet replace schools and parents in education and upbringing?]. Interdyscyplinarne Konteksty Pedagogiki Specjalnej, nr 20, Poznań 2018. Pp. 21-46. Adam Mickiewicz University Press. ISSN 2300-391X. DOI: 10.14746/ikps.2018.20.02

The core of the analysis is countering the myth that allegedly using new communications technologies by children and youths is toxic to their development. In the post-modern world, children enter into partner and educational relationships with their parents specifically thanks to their better abilities to use new media. Changes the science of upbringing and education management are also necessary.
\end{abstract}

KEY WORDS: new media, Internet, virtual network, upbringing, pseudo-upbringing, family, school, globalisation, nihilism

\section{Wstęp}

Zaproponowałem w tytule mojego tekstu pytanie, które - jak każde pytanie rozstrzygnięcia - ma w rzeczy samej dość łatwo dającą się przewidzieć pozytywną odpowiedź. Mimo to jednak wcale nie jest ona tak prosta, skoro żyjemy w dobie „płynnej rzeczywistości", pełnej zmieniających się znaczeń i systemowych rozwiązań w edukacji publicznej. Nauki pedagogiczne w Polsce nie mają problemu z odpowiedzią na tak sformułowane pytanie. Po co najmniej 
20 latach oswajania się i korzystania z nowych technologii w świecie globalnej i otwartej komunikacji wiemy dostatecznie wiele na temat ich pozytywnych i negatywnych uwarunkowań oraz następstw. Potoczna odpowiedź na retoryczne pytanie w tym zakresie może mieć zatem co najwyżej charakter zbliżony do stylistyki prezydenta RP Lecha Wałęsy („Jestem ZA, a nawet PRZECIW”) i brzmieć w sposób najprostszy z możliwych: TAK i NIE.

\section{Nauki o wychowaniu w świecie kryzysów i mitów}

Nauka nie jest od tego, by reagować na doraźne sytuacje kryzysowe i doniesienia $\mathrm{z}$ różnego rodzaju sondaży diagnostycznych, gdyż od tego są doświadczający ich i zapoznający się z nimi na co dzień - a ufam, że wykształceni i ustawicznie uczący się - profesjonalni pedagodzy, wychowawcy, nauczyciele, terapeuci i specjaliści w zakresie wywołanego, a rzekomo kryzysowego zjawiska. Rolą pedagogiki jako nauki jest przede wszystkim prowadzenie badań diagnostycznych, opisowych, wyjaśniających, ale także podstawowych w zakresie konstruowania teorii i modeli (meta)teoretycznych czy eksperymentalnych, by dzięki upowszechnianiu ich wyników i treści możliwe było:

- prowadzenie racjonalnej polityki oświatowej/edukacyjnej w państwie przez (oby) oświeconych władców,

- uruchamianie czy wspomaganie sił społecznych, w tym organizacji pozarządowych,

- współpracowanie pedagogów ze środowiskiem projektującym i wytwarzającym nowe technologie i narzędzia komunikacji,

- alfabetyzacja $\mathrm{w}$ powyższym zakresie naturalnych $\mathrm{i}$ zastępczych rodziców czy opiekunów dzieci,

- kształcenie i doskonalenie kadr pedagogicznych w kraju.

Naturalnych rodziców dzieci nic, nikt i nigdy nie jest $\mathrm{w}$ stanie zastąpić, niezależnie od tego, jak wyjątkowe, wspaniałe i nawet tanie będą nowe technologie, narzędzie komunikacji. Podkreślam NIKT, NIC, NIGDY. Mam tu na uwadze rodziców, którzy są szczę- 
śliwi z posiadania potomstwa, kochają je, troszczą się o nie, a tym samym mają pełnowartościową, normalną komunikację bezpośrednią ze sobą w rodzinie. Nawet w sytuacji czasowego lub dłuższego rozstania, oddalenia technika służy im tylko i wyłącznie do podtrzymania, utrwalania i pogłębiania wzajemnych więzi i otwartości, a nie zastąpienia ich. $W$ zdrowych środowiskach rodzinnych technologie cyfrowe sprzyjają zacieśnianiu więzi społecznych dzięki lepszej i szybszej możliwości komunikowania się np. rodziców z własnymi dziećmi za pomocą telefonów komórkowych.

Nie wyolbrzymiajmy zatem mitu o rzekomym i możliwym substytucie rzeczy tak, jakby mogły one być spersonalizowane i na odwrót, nie reifikujmy naszych dzieci, nie redukujmy ich do technologii, bo tam, gdzie rodzic przechodzi na komunikację pośrednią z własnym dzieckiem we własnym mieszkaniu (a to zaczyna mieć miejsce) oznacza, że w sensie psychospołecznym rezygnuje, wycofuje się z bycia rodzicem. Wówczas obciążanie mediów ZŁO-BYTEM jest znakomitą ucieczką od własnej odpowiedzialności wobec własnych dzieci za to, kim i jakimi się stają w tak konstruowanych relacjach.

To nie MEDIA niszczą więzi, gdyż te są następstwem oddziaływań pseudorodziców. Nowe media otwierają bezpośrednią, realną i pośrednią, wirtualną przestrzeń podopiecznym rodziców jako już NIE ICH - na nowe, ale $\mathrm{W}$ istocie obce im podmioty. $\mathrm{W}$ takiej sytuacji w grę zawsze wchodziły, wchodzą i będą wchodzić OBCE INTERESY z dobrą, ale i złą wolą, z pozytywnymi, ale i negatywnymi intencjami, jawnymi, ale i ukrytymi potrzebami uruchamiania oddziaływań na osobowość młodych pokoleń. W zakresie tak rozumianych wpływów MEDIA oraz WIRTUALNY ŚWIAT stają się albo pozytywnym współsprawcą, mentorem, doradcą, przyjacielem w rozwoju dzieci i młodzieży, albo czynnikiem destrukcyjnym, niszczącym, pośrednim dręczycielem czy podstępnym wrogiem. Zdarza się, że są wszystkim po trosze. W sytuacji psychospołecznego opuszczenia dziecka przez rodziców wszystko w jego życiu jest możliwe, aczkolwiek badania nad bliźniętami jednojajowymi wskazują, że jeśli mają właściwe wyposażenie genetyczne, to nie są na straconej pozycji. 
Pedagodzy wiedzą, że ok. 30\% rodziców w społeczeństwach względnie bogatych, rozwiniętych gospodarczo - a Polska do takich należy - stanowią tacy, którzy z różnych powodów nie chcieli mieć dzieci, toteż przyszły one na świat w nie zawsze sprzyjających okolicznościach i klimacie społeczno-emocjonalnym. Więzi z nimi nie było już od poczęcia i w okresie prenatalnym, a tym bardziej postnatalnym, toteż potrzebują one szczególnej bliskości, pozytywnych uczuć nawet wówczas, kiedy zdane są na zastępczych rodziców, na profesjonalnych wychowawców, nauczycieli począwszy od żłobka, przedszkola po powszechnie obowiązującą szkołę ${ }^{1}$ W sieci będą kanalizować swoje niezaspokojone potrzeby więzi, akceptacji, afiliacji itp., nakładając maski, by jako użytkownicy np. gier mogli wcielać się w role "odkrywców”, "poszukiwaczy towarzystwa", „wyczynowców” czy „zabójców”2. To zastępczy rodzice, instytucjonalni czy środowiskowi opiekunowie muszą zabiegać o ich akceptację, otwartość i gotowość do współdziałania, jeśli chcą być pedagogami w pełnym tego słowa znaczeniu, realizować założone funkcje i cele reprezentowanej przez siebie instytucji/placówki. Najpierw muszą zatem pozyskać DZIECKO, psychospołecznie „PRZYWIĄZAĆ” je do siebie, by podjąć się wraz z nim wspólnego trudu istnienia i rozwoju. Muszą wzajemnie uczyć się siebie, wzajemnie poznawać, by odpowiadać na swoje oczekiwania i potrzeby.

Drugą stroną tej sytuacji jest pozyskanie niepożądanych dla rodziców dzieci przez tych, dla których są one jedynie interesem, środkiem do ich najprzeróżniejszych celów. Media mogą być tu pomocne negatywnie albo pozytywnie. Negatywnie, jeśli są pokusą, pułapką, przynętą dla niegodnych celów, do krzywdzenia dzieci lub jako klienta do zarabiania na jego otoczkowych potrzebach (np. banki, producenci IT, przemysł farmaceutyczny, spożywczy, usługi paradmedyczne itp.), natomiast mogą być pomocne, jeśli staną się

${ }^{1}$ D. Kornas-Biela, Pedagogika prenatalna, [w:] Pedagogika. Subdyscypliny i dziedziny wiedzy o edukacji, red. Bogusław Śliwerski, tom 4, GWP, Gdańsk 2010.

2 T. Boellstorff, Dojrzewanie w second life. Antropologia człowieka wirtualnego, przeł. A. Sadza, Wydawnictwo UJ, Kraków 2012, s. 158. 
środkiem wołania o pomoc (np. niedoszli samobójcy, dzieci wykorzystywane seksualnie itp.) lub wsparciem dla ich indywidualnej ścieżki samokształcenia i rozwoju.

\section{Wrogość wobec dzieci}

Autor książki Zeit für Kinder ${ }^{3}$ wymienia dwa rodzaje wrogich wobec dziecka postaw osób dorosłych, a mianowicie: wrogość obiektywną i wrogość subiektywną. Ta pierwsza jest pochodną rozwiązań strukturalnych, a więc np. braku ochrony dzieci przed zbyt łatwym dostępem do demoralizujących treści i obrazów. Wrogiem obiektywnym dziecka staje się rzecznik Zła, wbrew własnej woli, blokujący lub degradujący rozwój psychofizyczny podopiecznego. Mamy na ten temat m.in. publikacje pod red. Józefa Bednarka i Anny Andrzejewskiej z APS4, Wojciecha Skrzydlewskiego i Stanisława Dylaka z UAM5, autorstwa Michała Klichowskiego i Hanny Krauze-Sikorskiej z UAM ${ }^{6}$ czy Stanisława Juszczyka7. Natomiast wrogość subiektywna jest wyrazem osobistej nienawiści do kogoś słabszego. Jest to typ racjonalnego sadysty, który doświadcza satysfakcji z fizycznego i/lub psychicznego znęcania się nad dziećmi. Pisze o tym na przykładzie zjawiska cyberbullyingu m.in. Jacek

${ }^{3}$ E. von Braunmühl, Zeit für Kinder. Theorie und Praxis von Kinderfeindlichkeit, Kinderfreundlichkeit, Kinderschutz. Zur Beseitigung der Unsicherheit im Umgang mit Kindern. Ein Lehrbuch, Fischer Taschenbuch Verlag, Frankfurt a. Main 1978, s. 24.

${ }^{4}$ Człowiek $w$ obliczu szans cyberprzestrzeni i świata wirtualnego, red. Józef Bednarek, Difin, Warszawa 2014.; Dzieci i młodzież w sieci zagrożonych realnych $i$ wirtualnych. Aspekty teoretyczne i empiryczne, red. Anna Andrzejewska, Difin, Warszawa 2014.

${ }^{5}$ Media. Edukacja. Kultura. W stronę edukacji medialnej, red. Wojciech Skrzydlewski, Stanisław Dylak, Polskie Towarzystwo Technologii i Mediów Edukacyjnych, Poznań - Rzeszów 2012.

${ }^{6} \mathrm{H}$. Krauze-Sikorska, M. Klichowski, Świat digital natives. Młodzież w poszukiwaniu siebie i innych, Wydawnictwo Naukowe UAM, Poznań 2013.

7 S. Juszczyk, Człowiek w świecie elektronicznych mediów - szanse i zagrożenia, Wydawnictwo Uniwersytetu Śląskiego, Katowice 2000. 
Pyżalski ${ }^{8}$. Ze względu na uwikłanie wychowania w ogół procesów społecznych, specyfikę wzajemnych relacji między wychowawcą a wychowywanym, wielość, w tym także sprzeczność czy konkurencyjność wzorów i podmiotów wychowania oraz odroczenie jego efektów w czasie mogą pojawić się w jego toku zdarzenia niekorzystne czy wręcz szkodliwe (pseudowychowawcze) dla rozwoju wychowanków.

$\mathrm{Na}$ ścianie jednego z domów w Lublinie dostrzegłem ogromnych rozmiarów reklamę, która przedstawiała młodego, eleganckiego mężczyznę a opatrzona była następującą sentencją: „BYCIE SOBĄ JEST LUKSUSEM". Otóż w normalnej rodzinie bycie sobą nie jest luksusem, tylko jest normą, oczywistością, natomiast $w$ rodzinie dysfunkcjonalnej, w której dziecko jest wyalienowane, ma poczucie bycia przeszkodą, obciążeniem itp. BYCIE W INTERNECIE z nałożoną maską anonimowości potwierdza obserwację antropologów kulturowych, etnografów wirtualnego świata oraz potwierdza doświadczenie takich dzieci, które można wyrazić komunikatami typu: „Tutaj przekonuję się, że mogę być naprawdę sobą, moim prawdziwym 'ja', Tu pokazujemy swoją duszę" czy „Tu łatwo mi być wieloma osobami jednocześnie" 9 .

Technologie internetowe są zatem nie dla wszystkich źródłem społecznej alienacji. Sądzę, że dzieci, które już są wyobcowane we własnej rodzinie, mogą odzyskać tożsamość, zrekonstruować osobowość „postrzegając swoje życie przez pryzmat możliwych sposobów życia oferowanych przez wszystkie rodzaje mass mediów"10. Nie łudźmy się i nie kreujmy takich oczekiwań, czy - jak to trafnie określał przed laty socjolog Jan Szczepański - nie generujmy potrzeb otoczkowych wśród naszych wychowanków w sytuacji, gdy nie są $\mathrm{w}$ stanie zaspokoić swoich podstawowych potrzeb pierwszego rzędu. Nigdy pośredni, bo wirtualny „dotyk”, ruch itp. nie bę-

8 J. Pyżalski, Agresja elektroniczna wśród dzieci i młodzieży, GWP, Sopot 2011; idem, Agresja elektroniczna i cyberbullying jako nowe ryzykowne zachowania młodzieży, Oficyna Wydawnicza „Impuls”, Kraków 2012.

${ }^{9}$ Ibidem, s. 158.

10 Ibidem, s. 162. 
dzie tym samym, co doznanie naturalnego, bezpośredniego kontaktu czy odczucie i przeżycie naturalnego ruchu. Nie muszę tego tym bardziej odnosić do sfery duchowej i psychicznej, emocjonalnej, wrażeniowej. Rzeczywistość jest bowiem tam, gdzie nie ma interne$\mathrm{tu}$, podobnie jak internet jest jedynie pośrednim dostępem do rzeczywistości nam bezpośrednio nieprzystępnej.

To, że świat wirtualny, online często funkcjonuje jako synonim świata prawdziwego, być może nawet $\mathrm{w}$ pewnym stopniu wysoce przeżywanego równie prawdziwie i równie ważnie - $\mathrm{z}$ racji odbieranych i przekazywanych mu bodźców - to jednak prawdziwym nie jest, gdyż nie taki jest jego ontologiczny status. On może i miewa konsekwencje $\mathrm{w}$ naszym życiu realnym, ale przecież nie jest $\mathrm{w}$ tym zakresie niczym nowym z psychospołecznego punktu widzenia (np. randka w ciemno była także $\mathrm{w}$ telewizji, a przyszłego partnera można równie dobrze poznać za pośrednictwem innych mediów, np. prasy). Nie muszę tego rozwijać $w$ tak szacownym gronie ekspertów.

Jednym z atrybutów rzeczywistości jest przestrzenność, toteż i pedagogika musi sytuować się $\mathrm{w}$ każdym miejscu przestrzeni realnej i wirtualnej oraz sama powinna posiadać jakąś strukturę przestrzenną. Debata o problemach socjalizacyjnych, wychowawczych czy dydaktycznych $w$ obu strefach nie jest przecież sporem bezcielesnych duchów bytujących poza przestrzenią rzeczywistej historii, gdyż dotyczy konkretnych postaci, nawet jeśli są one przedmiotem animacji, technologicznymi konstrukcjami. Można badać każdą $\mathrm{z}$ tych przestrzeni i włączać się $\mathrm{w}$ ich życie, gdyż każda $\mathrm{z}$ postaci kreuje lub współokreśla rzeczywisty sens życia każdego z nas. Nie można oddzielić ich fundamentów ontologicznych i ontycznych od aksjologicznych, bowiem - jak trafnie zwracał na przestrzeń spotkań filozof Andrzej Nowicki: „Jej części składowe mogą być: a) niezależne od siebie, b) jedna może służyć drugiej za fundament; c) mogą mieć wspólną granicę, wynikająca z podziału większego obszaru na części, d) mogą częściowo zachodzić na siebie, e) jedna może mieścić się w drugiej i f) mogą się wzajemnie przenikać"11.

${ }^{11}$ A. Nowicki, Spotkania w rzeczach, PWN, Warszawa 1991, s. 255. 
Badajmy zatem, dociekajmy, jak dochodzi do spotkań obu przestrzeni (realnej i wirtualnej) i istniejących w nich podmiotów oraz przedmiotów. Nie budujmy pedagogiki granic, bo jest to droga do samowykluczenia.

Współczesne nauki społeczne dekodują ponowoczesny świat jako sprzyjający fragmentaryzacji tożsamości osób, jej rozproszeniu, a nawet jej inscenizowaniu. Nie można zatem podchodzić do fenomenów ponowoczesnego świata tak, jakbyśmy nadal mieli do czynienia ze światem minionej epoki, światem nowoczesnym, gdyż nasze działania - mam tu na uwadze pedagogów - będą nieskuteczne, bo nieadekwatne do wolności i pluralizmu, heterogeniczności i nieustannego inscenizowania różnicy, a nie uniformizowania tożsamości naszych wychowanków. Jak pisze o tym Zbyszko Melosik:

W epoce nowoczesności granice tożsamości były jasno zdefiniowane, spójne, spójne i stabilne. Jej dyscyplinowanie opierało się na precyzyjnej odpowiedzi na pytanie: „kim wolno być, a kim być nie wolno”. Współcześnie dyscyplinowanie tożsamości polega na obowiązku bycia sfragmentaryzowanym - przekaz „musisz być taki a taki” zastąpiony został przekazem „możesz być każdy (jednocześnie). Mamy tu więc do czynienia, jak sądzę, z dyscyplinowaniem tożsamości za pomocą konstruowania poczucia wolności w sferze dokonywania wyborów konsumenckich (przy przyjęciu założenia, że tożsamość "rozgrywa się" głównie wokół konsumpcji) ${ }^{12}$.

\section{Rola wychowania w ponowoczesnym świecie}

Świat każdego dziecka, jak i dorosłego, włącznie z „ICH” światem we wszystkich jego odmianach zakłada DRUGICH jako współkonstytuujące go podmioty. INNI są dla podmiotu zawsze otwartą możliwością, niezależnie od tego, czy faktycznie w nim występują,

12 Z. Melosik, Tożsamość, ciało i władza. Teksty kulturowe jako (kon)teksty pedagogiczne, Edytor, Poznań - Torun 1996, s. 106-107. 
czy też pośrednio, wirtualnie. Nikt z nas nie może zanegować ani powstrzymać dostępu do czy obecności DRUGIEGO do czyjegoś JA, gdyż musiałby zakładać brak zdolności osoby do rozpoznawania możliwego współistnienia dwu światów. Dla pedagogów istotna jest odpowiedź na pytanie - Jak jest przeżywany przez naszych wychowanków świat wirtualny i co z tego świata "noszą” oni w sobie? Może warto sięgnać do kategorii intersubiektywności, która staje się jednym z podstawowych pojęć w naukach społecznych.

Przestrzeń relacji międzyludzkich, sfera tego, co międzyprzedmiotowe, i tego, co „publiczne" - bo o te wymiary właśnie chodzi, gdy mówimy o intersubiektywności - zakładana jest we wszystkich ważnych teoriach szeroko rozumianej humanistyki czy w prawodawstwie ${ }^{13}$.

Jeśli spojrzymy na wychowanie jako zjawisko pojawiające się "pomiędzy” wirtualnym nadawcą znaczeń a ich odbiorcą (wychowywanym), to nie sposób sprowadzić je do tego, co przynależy jedynie nadawcy (wychowawcy), ani integrować je tylko z wychowankiem, ani też podporządkować je jakimś ogólnym prawom.

To, co rozgrywa się pomiędzy nami, a nie należy do żadnej jednostki, ani też do wszystkich łącznie. W tym sensie tworzy ono ziemię niczyją, pogranicze, które zarazem łączy i dzieli. To, co obecne jest tylko w ten sposób, że wymyka się naszemu własnemu dostępowi, nazywamy obcym $^{14}$.

Wychowanie czy kształcenie w świetle tego podejścia nie jest samym tylko czyimś działaniem, ani też jego przedmiotem czy efektem, ale czymś, co zachodzi w przestrzeni międzypodmiotowej. Możemy zatem przyglądać się edukacji równocześnie z dwóch zaangażowanych $\mathrm{w}$ ten proces stron - podmiotu działającego (bezpośrednio lub pośrednio) i podmiotu doznającego czyichś działań (także bezpośrednio lub pośrednio) - jako czemuś jednemu.

${ }^{13}$ P. Makowski, Wymiary intersubiektywności. Stowo wstęne, [w:] Intersubiektywność, red. Piotr Makowski, Universitas, Kraków 2012, s. 7.

14 B. Waldenfels, Podstawowe motywy fenomenologii obcego, przeł. J, Sidorek, Oficyna Naukowa, Warszawa 2009, s. 108-109. 
Tym, co tu różne, to aspekty, lecz nie wychowanie, które jest czymś jednym. Owo patrzenie $z$ dwu różnych stron nie powinno być patrzeniem na dwie różne rzeczy, lecz na "tę samą rzecz". Patrzymy przez dwa różne okna, ale patrzymy do wnętrza tej samej sali. I tak jak stożek "rzucony” na jedną płaszczyznę przedstawia się jako koło, a „rzucony" na drugą płaszczyznę przedstawia się jako trójkąt, tak wychowanie "rzucone" na podmiot doznający jest czymś różnym od wychowania „rzuconego” na podmiot działający. Ale jak koło i trójkąt nie są stożkiem, tak i wychowanie nie jest tym czy tamtym aspektem wychowania ${ }^{15}$.

Nie można zatem tych dwóch światów postrzegać w izolacji, jako układu dwóch niezależnych i samoistnych elementów - podmiotów lub też budować wobec któregoś murów, gdyż one są obecne. Wszelki bowiem

(...) związek społeczny ma charakter żywego zespolenia. Nasza psychika jest bowiem $\mathrm{z}$ gruntu dwoista i funkcjonuje zawsze $\mathrm{w}$ kategoriach „ja” i „my”. Na tę dwoistość zwróciła też uwagę psychologia (...). Nie tak się więc mają rzeczy, jak przypuszczano dawniej, iż izolowana, gotowa, zamknięta osobowość ustosunkowuje się dowolnie do innych, równie niezależnych osobowości, ale od najwcześniejszych lat życia psychika nasza rozwija się przez odczuwanie nas i otoczenia, dostrzega i pojmuje obce "ja" w sobie, a własne w cudzych, przeżywa siebie w otoczeniu i otoczenie w sobie. (...) jednostka i społeczność nie są pojęciami substancyj, ale funkcyj i (...) dlatego wszelkie próby wyprowadzania przyczynowo-celowego bądź to jednostki ze zbiorowości, bądź to zbiorowości z jednostek są zupełnie fałszywe. Funkcje te mogą mieć wszakże różne napięcia i tym właśnie różnią się rozmaite formy stosunków społecznych. (...)

Pogłębienie życia osobowego staje się zarazem przyjęciem $\mathrm{w}$ siebie większych zakresów społecznych, a podniesienie intensywności życia psychicznego wokół nas działa pobudzająco na naszą psychikę. Ujmując to $\mathrm{w}$ kategorie dwoistości naszej psychiki, można powiedzieć, iż wzmocnienie kategorii ,ja” powoduje zarazem wzmocnienie kategorii „my” i odwrotnie. W ten sposób osobowość i społeczność przestają

${ }^{15}$ J. Filek, Pytanie o istotę wychowania, "Studia Filozoficzne” 1984, nr 4, s. 125. 
być nieruchomymi bytami, stają się przenikającymi się wzajemnie procesami ${ }^{16}$.

Dzisiaj częściej posługujemy się kategorią tożsamości, aniżeli osobowości, JA. Pojęcie to jest jednak tak samo abstrakcyjne jak powyższe, a nauki społeczne wcale nie dają nam jednoznacznego przekazu odpowiedzi na fundamentalne pytania:

Skąd wiemy, kim jesteśmy i na jakiej podstawie inni nas identyfikują? Jak nasze poczucie bycia niepowtarzalnymi jednostkami ma się do faktu, że zawsze i wszędzie dzielimy pewne aspekty naszej tożsamości z wieloma innymi ludźmi? Jak godzimy nasze poczucie ciągłości siebie ze świadomością, że dla różnych ludzi i w różnych sytuacjach jesteśmy inni? Czy możliwe jest, że staniemy się kimś lub czymś innym, niż jesteśmy teraz? Czy można po prostu „być sobą?”17

Kiedy zatem stawiamy pytanie o to, czy sieć zastąpi szkołę i rodziców w edukacji i wychowaniu - popełniamy błąd. Po pierwsze z tego powodu, że po pierwsze nie ma dzieci w ogóle czy rodziców w ogóle, że dzieci innym dzieciom, podobnie jak rodzice innym rodzicom nie są równi, a po drugie oba światy wzajemnie się przenikają, dopełniają, czy tego chcemy, czy nie. Jednostka może wychylić się w wirtualnym świecie ku INNEMU, OBCEMU, którego doświadcza w odmienny sposób, niż wówczas, kiedy staje wobec niego face to face, ale nie jest zobowiązujące do odwracalności relacji INNEGO do JA, skoro jej upośrednienie nie czyni jej symetryczną. Obie strony nie są dla siebie źródłem moralnej odpowiedzialności wobec siebie.

${ }^{16}$ L. Witkowski, Dwoistość jako kategoria i paradygmat w pedagogice polskiej (o pracach Bogdana Suchodolskiego metodologicznie inaczej), preprint referatu na konferencję „Problemy współczesnej metodologii” Komitetu Nauk Pedagogicznych PAN, Wydziału Pedagogiki i Psychologii Uniwersytetu w Białymstoku, Wszechnicy Mazurskiej w Olecku 11-12 września 2000 r. Olecko, Kraków - Torun - Warszawa 2000, s. 21-22.

17 S. Rudnicki, Ciato i tożsamość w internecie. Teoria. Dyskurs. Codzienność, SCHOLAR, Warszawa 2013, s. 27. 
Dobrze jest także wiedzieć, która kategoria rodziców i dzieci jest przedmiotem naszego poznania czy pedagogicznej troski. Wrogowie dzieci uczą się z internetu szybciej i więcej na temat możliwego ich wykorzystywania, niż dzieci mogłyby zdobyć wiedzę na temat tego, jak rozpoznawać subiektywnych i obiektywnych wrogów, jak się przed nimi obronić. Dorośli zawsze mieli i mają tę przewagę nad dziećmi, mimo że to one mogą lepiej i sprawniej serfować po sieci. Jeśli przyjąć za Zygmuntem Baumanem, że wszyscy mieszkańcy kuli ziemskiej podlegają nieodwracalnemu już procesowi globalizacji, to oznacza, że także dzieci są "globalizowane"18. Warto zatem, idąc śladami rozmyślań badaczy tego fenomenu, zastanowić się nad tym, co z tego wynika dla ludzi, co szczególnie niesie z sobą ten proces dla dzieci?

\section{Koniec geografii w globalnym świecie relacji międzyludzkich}

Jesteśmy świadkami końca geografii, gdyż odległości przestają już mieć znaczenie. Świat skurczył się dla wszystkich, choć nie dla wszystkich jest $w$ zasięgu ręki. Jednych globalizacja dzieli, a innych w czymś jednoczy. Pedagodzy stawiają sobie pytanie, w jakim stopniu proces ten uruchamia $\mathrm{w}$ odniesieniu do dzieci dodatkowe czynniki ich marginalizacji, a w jakim zakresie sprzyja ich rozwojowi? W jakim stopniu globalizacja rzutuje na sytuację dzieci w świecie? Czy można w niej dostrzec tak negatywne, jak i pozytywne strony?

Globalizację - zdaniem jednych - należy wspierać, według innych zaś zwalczać lub nią sterować czy nadzorować. Jeśli jednak przyjąć, że jest ona doznawaniem nowej jakości, to może warto przynajmniej przyglądać się temu, jak rzutuje ona na kształt dzieciństwa naszych dzieci.

${ }^{18}$ Z. Bauman, Globalizacja. I co z tego dla ludzi wynika, przeł. E. Klekot, PIW, Warszawa 2000. 
Tabela 1. Dwa wymiary dwóch światów (źródło: opracowanie własne)

\begin{tabular}{|l|l|l|}
\hline & \multicolumn{1}{|c|}{ To, co realne } & \multicolumn{1}{c|}{ To, co wirtualne } \\
\hline Aspekt pozytywny & Wychowalność & $\begin{array}{l}\text { Nie ma tu dwuznaczności, ale czysto } \\
\text { pozytywne intencje, gotowość wspar- } \\
\text { cia, pomocy, mentoring, coaching itp. }\end{array}$ \\
\hline Aspekt negatywny & Pseudowychowanie & $\begin{array}{l}\text { Ukryty program, potencjalna możli- } \\
\text { wość instrumentalnego potraktowania } \\
\text { INNEGO, wykorzystania go, manipu- } \\
\text { lowania nim itp. }\end{array}$ \\
\hline
\end{tabular}

Chodzi bowiem o to, by procesy globalizacyjne - nieuniknione, a może nawet historycznie konieczne - nie odbywały się bez nas. Nasza kultura rozwoju musi zmierzać do wynoszenia na możliwie najwyższy poziom tego, co w naszej rodzimej kulturze najcenniejsze ${ }^{19}$.

Człowiek potrzebuje pomocy w lepszym orientowaniu się $\mathrm{w}$ istniejących i konfrontowanych $\mathrm{z}$ nim innych kultur. Wychowanie i kształcenie powinny zatem pomagać $\mathrm{w}$ radzeniu sobie z pluralizmem ludzkich kultur, rozumieniem ich oraz przełamywaniem poczucia niepewności.

Poprzez dojrzałość wewnętrzną winniśmy podnosić to, co partykularne i najbardziej własne do tego, co uniwersalne. Doskonałe - ofiarować światu. I w ten, nie tylko bierny, ale przede wszystkim twórczy sposób stawać się uczestnikami globalizacji ${ }^{20}$.

Filozofia społeczna i socjologia w ponowoczesności zwracają uwagę na coraz silniejsze dystansowanie się jednostek ludzkich wobec wszystkiego tego, co jest społeczne, wspólnotowe, skupiając się głównie na tym, co jest osobiste i zależne od indywiduum. Wchodzimy w stan neonarcystycznego samouwielbienia. Pedagodzy nie powinni zatem pomijać nihilistycznego kontekstu inkulturacji młodych pokoleń. Jak pisze włoski psycholog i filozof Umberto Galimberti, kulturowy nihilizm uderzył w najsłabsze ogniwo ponowoczesnych społeczeństw, to znaczy w dzieci i młodzież,

19 W. Stróżewski, Kultura i rozwój, „Tygodnik Powszechny” 2001 nr 1, s. 12.

20 Ibidem. 
"(...) wkradając się do ich dusz, przenikając do ich myśli oraz do ich uczuć. W ten sposób demoluje ich perspektywy i wysusza ich marzenia"21. Nihilizm młodzieży wyrażają następujące symptomy:

1) brak zainteresowania szkołą, szykanowanie w szkołach osób słabszych. Kształcenie zmienia się w ekonomiczną rywalizację chłodnych i policzalnych nośników sukcesów, bez emocjonalnych więzi między sobą;

2) emotywna próżnia - jest wynikiem wchłaniania z mediów ekstremalnie emocjonalnych doznań bez zdolności ich selekcjonowania, opracowywania;

3) utrata zmysłu intymności - wstyd, hańba, nieśmiałość chroni naszą intymność, naszą wolność i jądro naszej osobowości, kiedy postanawiamy, jaki stworzymy rodzaj relacji z innymi. Programy typu reality show potwierdzają, że w społeczeństwie zanika rozdział między interioryzmem a eksterioryzmem, między dyskretnością, prywatnością a upublicznieniu swoich tajemnic;

4) ponętność narkotyków, dopalaczy;

5) znieczulanie na śmierć - codzienne bombardowanie w mediach koktajlem seksualizmu i przemocy. Śmierć stała się produktem, który w homogenicznym wirtualnym świecie nie ma większego znaczenia, żadnych negatywnych następstw;

6) obojętność, psychopatia, socjopatia - generacja $X$ i generacja $Q$;

7) rytualna przemoc $w$ czasie igrzysk, chuligaństwo na stadionach, udziału w przemocowych orgiach, ekstremalnych wydarzeniach, euforia z ekscesów, dokuczenia innym ${ }^{22}$.

Michael Adler z University of British Columbia w Vancouver wskazuje na podstawie przeprowadzonych badań na następujące cechy patologicznego narcysty:

- Ma zwiększone poczucie znaczenia (np. przerysowuje swoje osiągnięcia i uzdolnienia, oczekuje uznania zwierzchników bez odpowiadającego jemu efektów);

${ }^{21}$ Za: A. Rajský, Nihilistický kontext kultivácie mladého človeka,. Filozoficko-etický pohl'ad, Typi Universitatis Tyrnaviensis, Trnava 2009, s. 139.

22 Ibidem, s. 160-167. 
- Oddaje się fantazjom o swoim nieograniczonym sukcesie, mocy, doskonałości, pięknie czy idealnej miłości;

- Wierzy, że jest szczególny i osamotniony a wydaje mu się zrozumiałe, że powinien zbliżać się do innych osób (urzędów) wysoko postawionych;

- Oczekuje ciągłego podziwu;

- Ma poczucie bycia pożądanym tj. ma zawyżone oczekiwania;

- W postępowaniu z ludźmi zachowuje się konformistycznie: wykorzystuje innych do osiągania swoich celów;

- Traci zdolność współdoznawania; odrzuca uznawanie odczuć i potrzeby innych;

- Często zazdrości innym albo wierzy, że inni jemu zazdroszczą;

- Przejawia aroganckie, nadęte zachowania i postawy ${ }^{23}$.

\section{Znaczenie edukacji szkolnej}

Szkoła o tyle jest i będzie potrzebna młodemu pokoleniu także w XXI w., że może mu pomóc w odnalezieniu sensu życia, którego brak prowadzi do różnego rodzaju psychicznej traumy. Życie w nicości oznacza bowiem egzystencję $\mathrm{w}$ sterylnej kulturze, a więc w kulturze bez wizji przeszłości czy przyszłości, bez organizujących ją zasad, bez wyraźnych wartości i autorytetów.

Sens szkoły tkwi właśnie w tym, że jednostki uczą się w środowisku, podporządkowywać swoje indywidualne potrzeby interesom grupowym w odróżnieniu od środków masowej komunikacji, które stymulują indywidualne reakcje i prywatne doświadczenia ${ }^{24}$.

W zmieniających się społeczeństwach istnieje wystarczająca liczba dowodów na konieczność uczenia się w szkole zanim dzieci zaakceptują to jako wartość i ją zinterioryzują.

${ }^{23}$ K. Hvižd'ala, Interviewer aneb restaurování konteksti̊. Rozhovor s M. M. Marešovou, Portál, Praha 2010, s. 60-61.

24 N. Postman, Keine Götter mehr. Das Ende der Erziehung, Berlin Verlag, Berlin 1995, s. 66. 
Chodzi tu przede wszystkim o to, by stworzyć im odpowiednie otoczenie, w którym wspierana będzie ich współpraca, wrażliwość i odpowiedzialność za innych. Właśnie dlatego szkoła wymaga od uczniów, żeby $\mathrm{w}$ określonym miejscu i czasie postępowali zgodnie $\mathrm{z}$ określonymi zasadami jak np. podnoszenie ręki, kiedy chce się coś powiedzieć i niezabieranie głosu, kiedy mówią inni czy nieżucie gumy, niewstawanie przed dzwonkiem i niewychodzenie z klasy, oraz by mieli cierpliwość w stosunku do osób wolno się uczących. Proces ten określany jest jako akulturacja, czyli kreowanie cywilizowanych ludzi ${ }^{25}$.

Zdaniem Neila Postmana każdy, kto zajmuje się problemami kształcenia dzieci i młodzieży, musi rozstrzygnąć dwa zasadnicze problemy: techniczny i metafizyczny. Pierwszy z nich dotyczy metod i środków, dzięki którym młodzież zdobywa wiedzę, toteż pedagodzy zajmują się kwestią tego gdzie, kiedy i w jaki sposób powinno przebiegać nauczanie.

Warto sobie jednak przy tym uświadomić, że technika uczenia się jest bardzo często przeceniana, przez co przypisuje się jej więcej, niż ona na to $\mathrm{w}$ rzeczywistości zasługuje. Jak powiada stare przysłowie: - Wszystkie drogi prowadzą do Rzymu i wszystkie są właściwe. Podobnie jest $\mathrm{z}$ uczeniem się. Nikt nie może powiedzieć, że ten czy inny rodzaj uczenia się jest najlepszy ${ }^{26}$.

Innym człowiekiem można wprawdzie stać się dzięki temu, czego się uczymy, ale potrzebna jest do tego nie tylko jakaś wizja, koncepcja czy światopogląd, ile przede wszystkim jego uzasadnienie, a to już jest kwestią metafizyczną. Nie chodzi tu o sprawę motywacji do uczenia się, budzenia zaciekawień treściami kształcenia, składanie egzaminów czy odrabianie prac domowych, ale o coś abstrakcyjniejszego, nieuświadamianego sobie przez uczniów i nie dość łatwego do opisu, a bez czego szkoła nie może funkcjonować. Mam tu na uwadze świat ponadczasowych, uniwersalnych wartości, które w naszej Konstytucji i ustawie o systemie oświaty zostały określone jako wartości chrześcijańskie.

\footnotetext{
25 Ibidem, s. 68-69.

26 Ibidem, s. 70.
} 
Wychowawcy - w świetle analiz amerykańskiego socjologa kultury - należą do tej nielicznej grupy zawodowej, która jest szczególnie pełna uwielbienia dla boga technologii. Pojawiają się nawet pedagodzy, których zdaniem postęp $\mathrm{w}$ technologii przekazywania informacji jest tak duży, iż wkrótce szkoły nie będą potrzebne ani dzieciom, ani dorosłym. Poza klasą szkolną można bowiem uzyskać znacznie szybciej i więcej danych o interesujących nas sprawach. Tak np. Diane Ravitch b. asystentka Commissioner of Education (ranga sekretarza stanu w Ministerstwie Edukacji) opublikowała pogląd, że

w tym nowym świecie pedagogicznej obfitości tak dzieci, jak i dorośli będą w stanie oglądać we własnych domach programy telewizyjne, które im umożliwią uczenie się o odpowiadającej im porze. Jeśli mała Ewa nie będzie mogła zasnąć, to będzie mogła zamiast tego uczyć się algebry. W swojej domowej stacji edukacyjnej może włączyć interesujący ją program, który będzie interakcyjnym medium w uczeniu $\operatorname{się}^{27}$.

Postman krytykuje taką perspektywę, uważając, że nie mamy tu do czynienia z nową technologią, ale z pewnym rodzajem otwartego determinizmu obrazkowego świata i nierealnością ofert. Człowiek nie staje się wolny w swoich wyborach, ale dostosowuje swoje pragnienia do gotowych ofert przemysłu konsumpcyjnego. Nie da się ukryć, iż interesujący jest pomysł, by zamiast spędzać czas w ziejących nudą salach lekcyjnych, włączyć sobie domowy komputer i zrekonstruować symulację form życia biologicznego lub przeprowadzić telekonferencję na wybrany temat z naukowcem, który ma w tym zakresie określone sukcesy badawcze. Trudno sobie jednak wyobrazić, by naukowcy na całym świecie byli gotowi do uczestniczenia $\mathrm{w}$ tysiącu konferencjach telefonicznych $\mathrm{z}$ uczniami, którzy mają ochotę odrabiać z nimi zadania dydaktyczne. Postman formułuje zatem krytyczne pytania:

Czy podróż w świat wirtualny rzeczywiście wyeliminuje nudę z procesu uczenia się? Jeśli tak, to czy uczniowie będą chcieli po-

27 Ibidem. 
wrócić do świata realnego? Czyż nie jest tak, iż jak wszystkie technologie w przeszłości są one zawarciem swoistego rodzaju paktu z diabłem tzn. że dają coś, ale i odbierają? Czy wejście w świat rzeczywistości wirtualnej spowoduje, że technologia komputerowa stanie się główną motywacją, autorytetem i psychologicznym doradcą $\mathrm{w}$ rozwiązywaniu ludzkich problemów? Które treści nauczania będą zaniedbane, a które niemożliwe do realizacji?

Szkoły jako instytucje państwowe nie są w stanie zmieniać społeczeństwa, będąc jedynie lustrzanym odbiciem jego przekonań. Istnieją przy tym przeciwstawne orientacje co do celów edukacji szkolnej, bowiem część obywateli opowiada się za przystosowywaniem przez szkoły dzieci i młodzieży do akceptacji świata, z jego wszystkimi regułami, przymusami, ograniczeniami i przesądami na temat istniejącej kultury, druga część natomiast oczekuje od szkól, by kształciły krytyczne umysły, wychowywały uczniów do niezależności i samodzielności z dala od konwencjonalnych klisz ich epoki i z wystarczającą mocą do społecznych przemian.

Pedagogika medialna nie może ograniczać się do wiedzy o mediach, genezie ich powstania i ewolucji, do normatywnych westchnień, alternatywnych utopii (auto-)edukacyjnych, mnożenia sondażowych badań opinii na temat mediów, by wzbudzać lęk przed doraźnymi, a marginalnymi czy możliwymi zagrożeniami dla dzieci i młodzieży. To ma niewiele wspólnego z pedagogiką! Nauka powinna sprzyjać swoim interdyscyplinarnym podejściem do poznawania wirtualnego świata, rozpoznawania, monitorowania, prognozowania i podejmowania różnego rodzaju inicjatyw aplikacyjnych, eksperymentalnych, reformatorskich czy innowacyjnych z udziałem najbardziej kreatywnych edukatorów i naukowców, we współpracy z firmami hard- i softwarowymi, z kreatorami wirtualnego świata. Ta przestrzeń de facto niewiele się różni od tej, w której na co dzień spotykamy się ze sobą czy swoimi uczniami, wychowankami lub podopiecznymi.

Nie straszmy społeczeństw, a szczególnie młodego pokolenia mediami, wirtualnym światem, gdyż sami wykluczamy się $\mathrm{w}$ ten sposób z ich przestrzeni i pośredniej sfery publicznej jako niewiary- 
godni, bo politycznie poprawni komentatorzy ideologicznie marginalnych zjawisk. Patologie zawsze miały miejsce i mieć będą, bez względu na to, jak bardzo będziemy chcieli wprowadzać profilaktykę, izolować się od nich lub też wyolbrzymiać w nieuzasadniony naukowo sposób rzekomą powszechność ich występowania w całej lub większej części populacji. Pedagogika nigdy nie była i nie powinna być nauką straceńców, frustratów, pesymistów, mainstreamowych i dobrze sprzedających się $w$ mediach quasi-ekspertów i ekspertyz, gdyż ich wartość traci swoją moc ważności z dniem ich opublikowania. Podstawową rolą pedagoga jest prowadzenie wzwyż, pozytywne i czynne towarzyszenie innym $w$ ich życiu i rozwoju, czujne, wrażliwe i empatyczne współbycie z naszymi dziećmi i młodzieżą, a w dzisiejszych czasach może w sposób szczególny także z osobami dorosłymi i starszymi, bo znacznie powiększa się strefa analfabetyzmu komunikacyjnego $\mathrm{w}$ dobie nowych technologii i pogłębi luka pokoleniowa.

Zło jest medialne i świetnie się sprzedaje, ale na szczęście to nie ono przeważa w świecie, także wirtualnym. Pedagogika zaś nie jest od szerzenia marginaliów zła obu światów, gdyż w ten sposób przyczynia się do jego namnażania, powiększania, a nie kreowania pozytywnej socjalizacji, wychowania i samowychowania czy samorealizacji każdej osoby. Rozumiem, że można łatwo i szybko uzyskać na tej podstawie awans naukowy, świetnie prosperować $\mathrm{z}$ tytułu wygłaszania referatów, wyjazdów na zagraniczne konferencje, prowadzenia szkoleń, kursów i pisania ekspertyz, bo modą staje się to, co jest doraźnie niepokojące i znajduje się $\mathrm{w}$ centrum publicznej uwagi. Nie ma to jednak wiele wspólnego $\mathrm{z}$ nauką o wychowaniu. $Z$ powodu ZŁA, patologii, krzywd nie można ignorować sfery wirtualnego świata, a tym bardziej nią straszyć czy się na nią obrażać, gdyż byłoby to równoznaczne z wykluczaniem się jako pedagogów z możliwego i koniecznego działania, a przede wszystkim naszej obecności i zaangażowania.

To, że mamy archaiczny, z ubiegłego wieku system szkolny, centralistyczny, a więc totalnie nieprzystający ani ustrojowo, ani społecznie, a już na pewno nie pedagogicznie do ponowoczesnego 
świata, nie oznacza, że będzie lepiej, jak utrzymamy świetne samopoczucie rządzących ignorantów, by mogli dalej zaspokajać prywatne i partyjne potrzeby kosztem milionów objętych obowiązkiem szkolnych dzieci i młodzieży. Rozumiem, że można na tym świetnie zarabiać, że już niektórzy grzeją się do kolejnych milionowych dotacji na edukację, która będzie dzielona w samorządach. Czyż nie po to toczona była walka partyjnych sitw właśnie o sprawowanie władzy w samorządach przez kolejne lata? Tyle tylko, że te środki będą - podobnie jak dotychczasowe - wydane na prostą ich konsumpcję, reprodukcję władztwa i wzmocnienie kolesi, a nie zmianę jakości polskiej edukacji!

Bez decentralizacji i samorządności szkolnictwa i bez uspołecznienia zarządzania nim nie wyjdziemy z głęboko zakorzenionych w edukacji pozostałości "homosowietyzmu” i nie będziemy w stanie sprostać konstruowaniu nowoczesnego i efektywnego kształcenia oraz wychowywania młodych pokoleń w naszym kraju, nie sprostamy wyzwaniom ponowoczesności. Polskiej oświacie potrzebna jest strukturalna, programowa i metodyczna rewolucja, by z każdym kolejnym rokiem nie marnować na nią środków publicznych. Dla rozwoju emocjonalnego, społecznego i komunikacyjnego dzieci powinna być zwiększona troska o takie formy zajęć, jak: czytanie, opowiadanie, słuchanie, zabawy, przedstawienia i muzykowanie. Należy skończyć z jednorodną i jednolitą edukacją szkolną na rzecz wprowadzania różnorodności i wielokulturowości. Szkoła powinna stać się swoistego rodzaju domem uczenia się, laboratorium - warsztatem edukacyjnym, zaś nauczyciel powinien przejść na pozycję doradcy edukacyjnego i rozwojowego uczniów.

Kluczem do rozwiązania powyższych problemów edukacji może być m.in.:

- wykorzystanie nowoczesnych form integralnego uczenia się (bloki tematyczne zamiast przedmiotowego nauczania),

- multimedialne uczenie się (lub teleuczenie się),

- uczenie się warsztatowe (treningi różnych kompetencji) zamiast nauczania, 
- nauczyciel jako „trener - doradca” (,coach”) zamiast nadawcy wiedzy,

- odstąpienie od 45 minutowych lekcji,

- wprowadzenie form zajęć otwartych i metody projektów zamiast frontalnego nauczania skoncentrowanego na nauczycielu ${ }^{28}$.

Powyższe zmiany powinny uczynić proces uczenia się efektywniejszym, motywującym i dbającym o całościowy rozwój fizyczny, psychiczny, społeczny i polityczny uczniów. Zyskuje się bowiem dzięki temu więcej czasu na ruch, zabawy, współdziałanie z osobami znaczącymi, pracę z partnerem i grupową, rozwój kompetencji poznawczych, działaniowych i w zakresie rozwiązywania konfliktów, na prewencję, kompensację i integrację treści nauczania. Komputerowa „teleedukacja” w formie „domowej nauki” („Homelearnings") pozwala na optymalne wykorzystanie czasu do uczenia się, gdyż jej uczestnicy mogą sami regulować tempo opanowywania określonych treści, powtarzania ich, poszerzania i integrowania z innymi wiadomościami. Zwraca się także uwagę na to, iż teleedukacja redukuje u nauczycieli syndrom wypalenia zawodowego, minimalizuje problemy dyscyplinarne, niweluje efekty niesprawiedliwego oceniania uczniów (zaniżania czy zawyżania ich rzeczywistych osiągnięć).

Wyposażając szkołę w perfekcyjne programy edukacyjne, redukuje się też bezpośredni, negatywny wpływ niektórych nauczycieli na uczniów. Dzięki teleedukacji z zastosowaniem komputera można opanować wiedzę przekazywaną w toku lekcji w czasie krótszym o co najmniej trzy tygodnie, a przy tym o ten sam okres redukcji tempa uczenia się powiększa się trwałość zapamiętywanych treści. Internet nie jest jednak internatem, a zatem obcowanie uczniów z multimedialnym światem musi być odpowiednio dozowane. Należy w nich ukształtować też krytyczny dystans do niego, aby uczniowie nie zostali zniewoleni przez media. Nauczyciele zy-

28 P. Struck, Erziehung von gestern, Schüler von heute, Schule von morgen, München, Carl Hanser Verlag, Wien 1997. 
skują czas na kształcenie wśród uczniów kompetencji, które zaniedbuje teleedukacja, a mianowicie twórczość, wrażliwość społecznomoralna, wprowadzanie $\mathrm{w}$ świat wartości, aktywność ruchowa, nawiązywanie relacji społecznych, zaspokajanie potrzeb emocjonalnych, radzenie sobie z sytuacjami konfliktowymi itp.

Demokracja wymaga nie tylko społecznej, ale i politycznej dojrzałości od absolwentów szkól, toteż niezmiernie ważne jest przygotowywanie młodego pokolenia do odpowiedzialnego wyboru wartości i podejmowania zgodnie $\mathrm{z}$ nimi decyzji. To społeczeństwo przemysłowe potrzebuje szkoły nauczającej, podającej wiedzę, zaś społeczeństwo informatyczne powinno ten typ instytucjonalnej edukacji zastąpić szkołą - laboratorium (Lernwerkstatt), w której dominować będzie kształcenie kompetencji kluczowych jak umiejętność zdobywania informacji i działania, zdolność do współdziałania w grupie, twórczość i umiejętność myślenia globalnego.

Nawet wówczas, kiedy szkoła musiałaby ustąpić miejsca edukacji na odległość, to i tak nadal będziemy ją nazywać szkołą, choć już inaczej będziemy ją postrzegać. Zostaną z niej usunięte programy nauczania, które tłumią twórczość uczniów. Nie będzie się także dzielić uczniów na zespoły klasowe zgodnie $\mathrm{z}$ ich wiekiem życia, gdyż $w$ ten sposób uniemożliwia im się wzajemne uczenie się od siebie. Szkoła przyszłości będzie bardziej naturalna i organizowana na wzór wychowywania małych dzieci to znaczy, że uczenie się, życie i miłość nie będą w niej od siebie oddzielane. Praca $\mathrm{z}$ komputerem stworzy im ogromne możliwości rozwijania swojego potencjału twórczości i osiągnięć. Będą mogły komponować muzykę, pisać, czytać, rysować, liczyć, komunikować się czy po prostu bawić. Nawet, jeśli ktoś uważa, że w swojej odpowiedzi na tytułowe pytanie mojego tekstu ma racje,

to wcale nie oznacza, że racja ta odnosi się do wszystkiego, a to, że nie ma się racji, nie oznacza, że nie ma się jej w odniesieniu do niczego ${ }^{29}$.

${ }^{29}$ J.-CV. Kaufmann, Ego. Socjologia jednostki. Inna wizja człowieka i konstrukcji podmiotu, przeł. K. Wakar, Oficyna Naukowa, Warszawa 2004, s. 127. 


\section{Inkontrologia wyjściem ku zdrowym relacjom międzyludzkim}

Filozof społeczny, a zarazem twórca inkontrologii - Andrzej Nowicki wskazał na możliwości przygotowywania przestrzeni wspólnych spotkań pedagogów, psychologów, nauczycieli, terapeutów, księży, opiekunów, rodziców itp., dzięki którym możliwe będzie pogodzenie dwóch światów codziennego życia dzieci i dorosłych, a mianowicie:

1) jeżeli chcemy dostrzec pozytywne wartości, ale i ostrzec przed negatywnymi doświadczeniami osób spotykających się $\mathrm{z}$ nimi $\mathrm{w}$ obu przestrzeniach (realnej i wirtualnej), to warto identyfikować wzajemne oczekiwania, czyli gorące pragnienia, aby to, co się odbyło i udało albo co dopiero projektujemy, w wyniku troski o jego przebieg lub obaw, o wynikające z niego zakłócenia, sprzyjało pożądanym i dobrym skutkom;

2) „Wychodząc z założenia, że 'źródła nie zapytywane milczą', należy formułować najważniejsze pytania, które - jak potężne magnesy - będą wymagały odpowiedzi, oddzielając to, co istotne, od tego, co drugorzędne" 30 ;

3) "owocnymi i wzbogacającymi nas spotkaniami są przede wszystkim spotkania z tym, co inne, nowe, odmienne toteż należy wypełnić przestrzeń spotkania wrażliwością na inność, nowość, odmienność, niezwykłość, różnorodność" 31 ;

4) "owocnym spotkaniem nie jest takie spotkanie, które odbiera nam naszą osobowość, ale takie, które ją wzbogaca, toteż należy wypełnić przestrzeń planowanego spotkania postawą krytyczną, oceniającą w sposób samodzielny wszystkie treści spotkania"32;

5) „najważniejszym elementem umysłowej samodzielności, warunkującym posuwanie się naprzód, jest ujmowanie każdego

30 A. Nowicki, Spotkania w rzeczach, PWN, Warszawa 1991, s. 260.

31 Ibidem, s. 261.

32 Ibidem. 
przedmiotu (a także podmiotu), a więc i spotkania w aspekcie jego możliwości bycia innym, niż jest”33;

6) „wypełnienie przestrzeni planowanych spotkań myślami i przedmiotami jest kompozycją, której walory mogą uczynić przestrzeń spotkań dziełem sztuki, a więc czymś, z czym warto się spotykać.

7) Celem spotkania nie może być wyłącznie wzbogacanie własnej osobowości osiągane drogą interioryzacji najcenniejszych wartości niesionych przez spotkane przedmioty(i podmioty), ale także i przede wszystkim wzbogacanie istniejącego świata dzieł ludzkich przez wytwarzanie nowych wartości. Tak więc przestrzeń spotkania powinna być wypełniona także tym, co wykracza poza spotkanie, czyli perspektywę eksterioryzacji naszej osobowości, która wzbogacana przez to spotkanie stworzy nowe dzieła, takie, których dotąd jeszcze nie było"34.

Internet zmienił świat, a świat zmienia internet. Edukacja nie może być spóźnionym włóczęgą w sieci.

Świat nie tyle się obsuwa, co galopuje w stronę nowej transnarodowej dystopii. [...] Internet, nasze najlepsze narzędzie służące wyzwoleniu, został przekształcony $\mathrm{w}$ najniebezpieczniejszego pomocnika totalitaryzmu, a jakim kiedykolwiek mieliśmy do czynienia. Internet stał się zagrożeniem dla ludzkiej cywilizacji. Te transformacje dokonały się po cichu, gdyż świadome ich osoby pracują w globalnym przemyśle inwigilacyjnym i nie mają motywacji, żeby przemówić. Pozostawiona w aktualnej trajektorii cywilizacja globalna $\mathrm{w}$ ciągu kilku lat stanie się postmodernistyczną dystopią inwigilacyjną, z której nikt poza najlepiej wyszkolonymi jednostkami nie będzie w stanie uciec $^{35}$.

Pedagogika jako nauka nie może być na czyichkolwiek usługach, ani rządu, ani rynku, a tym bardziej mediów informacyjnych,

33 Ibidem, s. 262.

34 Ibidem, s. 262-263.

35 J. Assange, J. Appelbaum, A. Müller-Maguhn, J. Zimmermann, Cyberpunks. Wolność i przyszłość internetu, przeł. Marcin Machnik, Wydawnictwo HELION, Gliwice 2013. 
gdyż pseudosondażami wprowadza w błąd władze i opinię publiczną, nie dając im nic w zamian. To interesariusze powinni być zainteresowani korzystaniem z prac badawczych, rzeczywiście naukowych, a nie sondażowych, by odpowiedzialnie kreować własne zadania (polityczne, oświatowe, producenckie, innowacyjne itp.). Skończmy zatem z biadoleniem. Jeśli w tytule tej debaty jest mowa o wyzwaniach, to warto dostrzec, że nie są one tak dla pedagogiki, jak i innych nauk społecznych, humanistycznych czy medycznych czymś nowym. Człowiek nadal jest tą samą istotą, która rozwija się i potrzebuje społecznego, w tym także profesjonalnego wsparcia, nawet wówczas, kiedy zostanie już do końca poddany zewnętrznej inwigilacji i częściowo zaimplantowany elektroniką. Nauczycieli, opiekunów, wychowawców nie zastąpią roboty w tej roli, co nie oznacza, że roboty nie są potrzebne w edukacji szkolnej.

\section{Bibliografia}

Assange J., Appelbaum J., Müller-Maguhn A., Zimmermann J., Cyberpunks. Wolność i przysztość internetu, przeł. Marcin Machnik, Wydawnictwo HELION, Gliwice 2013.

Bauman Z., Globalizacja. I co z tego dla ludzi wynika, przeł. E. Klekot, PIW, Warszawa 2000.

Boellstorff T., Dojrzewanie w second life. Antropologia człowieka wirtualnego, przeł. A. Sadza, Wydawnictwo UJ, Kraków 2012.

Braunmühl von E., Zeit für Kinder. Theorie und Praxis von Kinderfeindlichkeit, Kinderfreundlichkeit, Kinderschutz. Zur Beseitigung der Unsicherheit im Umgang mit Kindern. Ein Lehrbuch, Fischer Taschenbuch Verlag, Frankfurt a. Main 1978.

Człowiek w obliczu szans cyberprzestrzeni i świata wirtualnego, red. Józef Bednarek, Warszawa, Difin S.A. 2014; Dzieci i młodzież w sieci zagrożonych realnych $i$ wirtualnych. Aspekty teoretyczne i empiryczne, red. Anna Andrzejewska, Difin S.A. , Warszawa 2014.

Filek J., Pytanie o istotę wychowania, "Studia Filozoficzne" 1984, nr 4.

Hvižd'ala K., Interviewer aneb restaurování kontekstů, Rozhovor s M.M. Marešovou, Portál, Praha 2010.

Juszczyk S., Człowiek w świecie elektronicznych mediów - szanse i zagrożenia, Wydawnictwo UŚl, Katowice 2000. 
Kaufmann J.-CV., Ego. Socjologia jednostki. Inna wizja człowieka i konstrukcji podmiotu, przeł. K. Wakar, Oficyna Naukowa, Warszawa 2004.

Kornas-Biela D., Pedagogika prenatalna, [w:] Pedagogika. Subdyscypliny i dziedziny wiedzy o edukacji, red. Bogusław Śliwerski, tom 4, GWP, Gdańsk 2010.

Krauze-Sikorska H., Klichowski M., Świat digital natives. Młodzież w poszukiwaniu siebie i innych, WN UAM, Poznań 2013.

Makowski P., Wymiary intersubiektywności. Stowo wstępne, [w:] Intersubiektywność, red. Piotr Makowski, Universitas, Kraków 2012.

Media. Edukacja. Kultura. W stronę edukacji medialnej, red. Wojciech Skrzydlewski, Stanisław Dylak, UAM, Poznań - Rzeszów 2012.

Melosik Z., Tożsamość, ciało i władza. Teksty kulturowe jako (kon)teksty pedagogiczne, Edytor, Poznań-Torun 1996.

Nowicki A., Spotkania w rzeczach, PWN, Warszawa 1991.

Struck P., Erziehung von gestern, Schüler von heute, Schule von morgen, Carl Hanser Verlag, München, Wien 1997.

Postman N., Keine Götter mehr. Das Ende der Erziehung, Berlin Verlag, Berlin 1995.

Pyżalski J., Agresja elektroniczna wśród dzieci i młodzieży, GWP, Sopot 2011; tenże, Agresja elektroniczna $i$ cyberbullying jako nowe ryzykowne zachowania młodzieży, Oficyna Wydawnicza „Impuls”, Kraków 2012.

Rajský A., Nihilistický kontext kultivácie mladého človeka. Filozoficko-etický pohl'ad, Typi Universitatis Tyrnaviensis, Trnava 2009.

Rudnicki S., Ciało i tożsamość w internecie. Teoria. Dyskurs. Codzienność, WN SCHOLAR, Warszawa 2013.

Stróżewski W., Kultura i rozwój, „Tygodnik Powszechny” 2001, nr 1, s. 12.

Szkudlarek T., Media. Szkic z filozofii i pedagogiki dystansu, Oficyna Wydawnicza „Impuls”, Kraków 1998 (II wyd.).

Waldenfels B., Podstawowe motywy fenomenologii obcego, przeł. J. Sidorek, Warszawa 2009.

Witkowski L., Dwoistość jako kategoria i paradygmat w pedagogice polskiej (o pracach Bogdana Suchodolskiego metodologicznie inaczej), preprint referatu na konferencję „Problemy współczesnej metodologii" Komitetu Nauk Pedagogicznych PAN, Wydziału Pedagogiki i Psychologii Uniwersytetu w Białymstoku, Wszechnicy Mazurskiej w Olecku 11-12 września 2000 r. Olecko, Kraków - Toruń - Warszawa 2000. 